\title{
Studi tentang pelaksanaan supervisi pembelajaran pada program keahlian teknik komputer dan informatika Sekolah Menengah Kejuruan (SMK) di Kota Batu
}

\author{
Gisra Rahmadhita ${ }^{1}$, Tri Atmadji Sutikno ${ }^{2}$, I Made Wirawan ${ }^{3}$ \\ 1. Universitas Negeri Malang, Indonesia | gisradhita@gmail.com \\ 2. Universitas Negeri Malang, Indonesia | tri.atmadji.ft@um.ac.id \\ 3. Universitas Negeri Malang, Indonesia | made.wirawan.ft@um.ac.id
}

\begin{abstract}
Abstrak
Penelitian ini bertujuan untuk mengetahui tingkat pelaksanaan supervisi pembelajaran. Bentuk penelitian adalah deskriptif kuantitatif. Penelitian dilaksanakan di SMK Kota Batu jurusan TKJ, MM, RPL dengan jumlah populasi sebesar 26 orang. Populasi pada penelitian ini adalah semua guru yang mengajar di program keahlian Teknik Komputer dan Informatika kelompok mata pelajaran produktif di SMK batu. Instrumen pengumpulan data menggunakan angket. Dalam penelitian ini validitas konstruk dapat dilakukan dengan meminta bantuan para ahli (judment expert) yaitu Ahmad Mursyidun Nidhom, M.Pd. dan Dila Umnia Soraya, M.Pd. dengan hasil perhitungan $86 \%$ pada kriteria valid. Penelitian menemukan pelaksanaan supervisi pembelajaran terlaksana dengan baik. Pada bagian penyusunan rencana kegiatan tahunan dan pelaksanaan penilaian hasil belajar masuk kategori baik. Sedangkan untuk indikator pelaksanaan kegiatan pembelajaran dengan kategori sangat baik.
\end{abstract}

Kata Kunci

Supervisi Pembelajaran, SMK, Teknik Komputer dan Informatika

TEKNO Vol. 27 Issue 1, p15-29 | Jurusan Teknik Elektro, Universitas Negeri Malang, Indonesia | Maret 2017

G. Rahmadhita., T.A. Sutikno., I.M.Irawan.| Studi tentang pelaksanaan supervisi pembelajaran pada... 


\section{TEKNO Jurnal Teknologi, Elektro, dan Kejuruan}

http://journal2.um.ac.id/index.php/tekno | ISSN 1693-8739

\section{Pendahuluan}

Perkembangan ilmu pengetahuan dan teknologi semakin mendorong upaya-upaya pembaharuan pemanfaatan teknologi dalam proses belajar. Guru dituntut mampu mengoptimalkan fasilitas sekolah, terutama teknologi informasi terbaru dalam rangka meningkatkan kwalitas pembelajaran. Selain itu, guru juga perlu memiliki keterampilan dalam mengembangkan skenario pembelajaran agar pelaksanaannya sesuai dengan karakter peserta didik dan kondisi sekolah. Oleh sebab itu, perlu diadakan sistem pembimbingan untuk membantu guru menjalankan tugasnya tersebut.

Peraturan Pemerintah RI Nomor 32 Tahun 2013 tentang perubahan atas peraturan pemerintah Nomor 19 tahun 2005 tentang Standar Nasional Pendidikan, Pasal 1 ayat 31, menerangkan bahwa kementrian menunjuk Lembaga Penjaminan Mutu Pendidikan (LPMP) yang berkedudukan di provinsi untuk membantu Pemerintah Daerah dalam bentuk supervisi, bimbingan, arahan, saran, dan bantuan teknis kepada satuan pendidikan dasar dan menengah serta Pendidikan Nonformal, dalam berbagai upaya penjaminan mutu satuan pendidikan untuk mencapai Standar Nasional Pendidikan.

Sekolah sebagai lembaga pendidikan wajib meningkatkan mutu pendidikannya secara integral dan komprehensif. Minimal sekolah tersebut harus memenuhi Standar Nasional Pendidikan (SNP) dan melaksanakan Manajemen Berbasis Sekolah (MBS), sehingga untuk meningkatkan mutu pendidikan sekolah keberadaan pengawas sangat dibutuhkan sekolah agar mampu melaksanakan manajemen dan mampu memenuhi SNP yang telah ditetapkan. Supervisi dalam pendidikan diyakini dapat meningkatkan kwalitas dan mutu para pendidik di sekolah. Secara umum supervisi dapat diartikan sebagai pengarah serta pengendalian kepada tingkat anak buah (bisa berarti karyawan atau anak didik) yang berada di bawahnya dalam suatu organisasi atau kelompok dalam petunjuk pelaksanaan supervisi pendidikan di sekolah (Daryanto \& Rahmawati, 2015).

Pengawas adalah guru yang berstatus pegawai negeri sipil yang diangkat dan diberi tugas, tanggung jawab dan wewenang oleh pejabat yang berwewenang untuk melaksanakan pengawasan akademik dan pengawasan manajerial pada satuan pedidikan atau sekolah dalam satu kabupaten/kota, yang dipimpin oleh seorang koordinator pengawas (Barnawi \& Arifin, 2014). Peran pengawasan pendidikan diatur secara khusus dalam Peraturan Pemerintah Nomor 19 Tahun 2005 Pasal 55 dan 57 tentang Standar Pengelolaan yang meliputi pemantauan, supervisi, evaluasi, pelaporan, dan tindak lanjut hasil pengawasan. Peraturan Menteri Pendidikan Nasional Nomor 21 Tahun 2010 tentang tugas pokok pengawas sekolah adalah melaksanakan tugas pengawasan akademik dan manajerial pada satuan pendidikan yang meliputi penyusunan program pengawasan, pelaksanaan pembinaan terhadap guru dan kepala sekolah, pemantauan pelaksanaan delapan standar nasional pendidikan, penilaian kinerja guru dan kepala sekolah, pembimbingan dan pelatihan profesional guru, evaluasi hasil pelaksanaan program pengawasan, dan pelaksanaan tugas kepengawasan di daerah khusus.

TEKNO Vol. 27 Issue 1, p15-29 | Jurusan Teknik Elektro, Universitas Negeri Malang, Indonesia | Maret 2017 G. Rahmadhita., T.A. Sutikno., I.M.Irawan.| Studi tentang pelaksanaan supervisi pembelajaran pada... 


\section{TEKNO Jumal Teknologi, Eektro, dan Keivuruan}

http://journal2.um.ac.id/index.php/tekno | ISSN 1693-8739

Supervisi pembelajaran sebenarnya sangat diharapkan untuk merubah dan memperbaiki iklim sekolah. Supervisi dapat dijadikan tonggak untuk melakukan evaluasi dan solusi dari permasalahan yang terjadi dalam proses pembelajaran di sekolah. Pengawas sekolah diharapkan dapat berperan ekstra dalam membimbing dan membantu guru untuk menyelesaikan setiap permasalahan yang ada, sehingga diharapkan pengawas sekolah memiliki kompetensi yang baik agar dapat terlaksananya supervisi di sekolah (Barnawi \& Arifin, 2014:15).

Supervisi bertujuan untuk memberikan layanan dalam meningkatkan kualitias dan profesionalisme guru. Supervisi berfungsi membantu memberi suport dan mengajak guru ikut serta untuk memperbaiki dan menilai pelaksanaan pembelajaran di kelas (Aqib \& Rohmanto, 2007). Selain itu, supervisi dapat dijadikan sebagai tahapan untuk mengkoordinasikan, menstimulasi, dan mengarahkan pertumbuhan guru-guru, sehingga melalui supervisi guru mendapatkan layanan dalam perbaikan diri (Imron, 2012).

Berdasarkan hasil observasi yang dilakukan pada 26 Mei 2016 oleh pengawas di SMK kota Batu diketahui bahwa supervisi oleh pengawas sekolah telah dilaksanakan dan menunjukkan bahwa hasil kinerja guru di belum maksimal. Hal ini disebabkan oleh beberapa hal, antara lain sebagai berikut: (1) Adanya kebijakan pemerintah yang mewajibkan guru untuk melakukan penelitian untuk kenaikan pangkatnya. Hal ini menyebabkan fokus mengajar guru teralihkan dimana tugas guru sebagai tenaga pengajar yang mampu melakukan penelitian tindakan kelas. Namun permasalahan yang muncul yaitu guru masih belum memiliki kwalitas diri yang baik untuk melakukan penelitian dengan baik dan guru belum bisa dalam menyeimbangkan antara proses pembelajaran dan penelitian yang dilakukan.; (2) Jumlah pengawas yang tersedia di lapangan tidak sebanding dengan guru yang disupervisi. Hal ini seringkali menyebabkan pengawas kewalahan dan tidak jarang hasilnya juga kurang memuaskan.; (3) Perubahan kurikulum yang terlalu sering dengan tempo yang singkat. Hal ini menjadi masalah ketika ditemukan kesenjangan personal guru dalam menyesuaikan dengan peraturan baru. Sehingga energi dan waktu supervisor banyak terkuras untuk membantu guru-guru tersebut. Akhirnya keadaan ini berimbas pada kewajiban penting supervisor yang lain, seperti menyusun program pengawasan, melaksanakan pembinaan guru, melaksanakan evalusi hasil pelaksanaan program pengawasan, membimbing profesional guru, pelaporan hasil pengawasan dan lain sebagainya.

Dari hasil observasi tersebut dapat disimpulkan bahwa guru masih memiliki kesulitan dalam mengikuti perkembangan pendidikan, baik dalam penyusunan perangkat pembelajar maupun proses belajar mengajar di kelas. Penyelesaian permasalahan ini dapat dilakukan dengan melakukan evaluasi pelaksanaan supervisi di sekolah oleh pengawas. Hal ini disebabkan karena keterlaksanaan supervisi di sekolah akan berpengaruh sangat baik terhadap peningkatan kwalitas guru di sekolah. Guru dapat digunakan sebagai informan yang dapat memberikan informasi tentang proses pelaksanaan supervisi di sekolah.

TEKNO Vol. 27 Issue 1, p15-29 | Jurusan Teknik Elektro, Universitas Negeri Malang, Indonesia | Maret 2017 G. Rahmadhita., T.A. Sutikno., I.M.Irawan.| Studi tentang pelaksanaan supervisi pembelajaran pada... 


\section{TEKNO Jurnal Teknologi, Elektro, dan Kejuruan}

http://journal2.um.ac.id/index.php/tekno | ISSN 1693-8739

Penelitian ini diharapkan dapat memberikan kontribusi untuk penelitian lebih lanjut mengenai supervisi pembelajaran, standar dan teknis pelaksanaannya, sehingga menghasilkan konsep supervisi pembelajaran terbaik untuk diterapkan di sekolah kejuruan ataupun tingkat sekolah lain. Penelitian ini bertujuan untuk mengetahui tingkat pelaksanaan supervisi pembelajaran.

\section{Metode}

Rancangan penelitian ini merupakan penelitian secara deskriptif kuantitatif. Penelitian deskriptif bertujuan untuk mengungkap dan mendeskripsikan, serta memetakan suatu peristiwa urgen yang terjadi pada masa kini (Mukhadis, 2016). Tujuan penelitian ini adalah untuk memperoleh informasi tentang seberapa tinggi pelaksanaan supervisi program keahlian Teknik Komputer dan Informatika di Sekolah Menengah Kejuruan (SMK) Kota Batu. Data yang digunakan adalah data kuantitatif, dimana data penelitian berupa angka-angka yang berasal dari parameter objektif hasil pengisian kuisioner oleh subjek penelitian untuk memperkuat data yang dideskripsikan.

Populasi dalam penelitian merupakan wilayah yang ingin diteliti oleh peneliti. Populasi adalah wilayah generalisasi yang terdiri atas obyek atau subyek yang mempunyai kwalitas dan karakteristik tertentu yang diterapkan oleh peneliti untuk dipelajari dan kemudian ditarik sebuah kesimpulan (Sugiyono, 2003). Populasi dalam penelitian ini adalah seluruh guru produktif SMK Kota Batu yang mempunyai program keahlian Teknik Komputer dan Informatika. Pemilihan guru sebagai populasi penelitian karena guru telah mendapatkan supervisi dari pengawas sekolah. Berdasarkan hal tersebut dapat dikatakan bahwa informasi dalam mengevaluasi keterlaksanaan supervisi dapat digali dari guru tersebut. Jumlah populasi guru SMK Program Keahlian Teknik Komputer dan Informatika di Kota Batu dapat dilihat pada Tabel 1 (Tata Usaha SMK Islam, Ma'arif, Brawijaya, Bhinneka dan SMKN 3 Batu, 2017)

Tabel 1 Data Jumlah Populasi Guru SMK Program Keahlian Teknik Komputer dan Informatika di Kota Batu

\begin{tabular}{clc}
\hline No & \multicolumn{1}{c}{ Nama Sekolah } & Produktif \\
\hline 1. & SMK 3 Batu & 6 \\
2. & SMK Islam Batu & 6 \\
3. & SMK Ma'arif Batu & 8 \\
4. & SMK Brawijaya & 4 \\
5. & SMK Bhinneka Tunggal Ika Indonesia Batu & 2 \\
\hline & Total & 26 \\
\hline
\end{tabular}

Instrumen penelitian adalah alat atau fasilitas yang digunakan oleh peneliti dalam megumpulkan data agar pekerjaanya lebih mudah dan hasilnya lebih baik, dalam arti lebih cermat, lengkap, dan sistematis sehingga lebih mudah diolah (Winarno, 2013). Instrumen penelitian yang digunakan dalam penelitian ini adalah kuisioner. Kuisioner merupakan teknik pengumpulan data yang dilakukan dengan cara memberi seperangkat pertanyaan atau 


\section{TEKNO Jurnal Teknologi, Elektro, dan Kejuruan}

http://journal2.um.ac.id/index.php/tekno | ISSN 1693-8739

pernyataan tertulis kepada responden untuk dijawabnya (Sugiyono, 2003). Tujuan peneliti ingin memperoleh data yang sistematis meliputi pelaksanaan supervisi pembelajaran pada program keahlian Teknik Komputer dan Informatika di Sekolah Menengah Kejuruan (SMK) Kota Batu.

Penelitian ini menggunakan angket tertutup yang pertanyaannya dibatasi oleh beberapa opsi jawaban. Angket yang digunakan pada penelitian ini menggunakan Skala Likert dengan empat skala. Alternatif jawaban yaitu (A) Selalu, (B) Sering, (C) Kadang-Kadang, dan (D) Tidak Pernah. Modifikasi skala linkert dengan empat jawaban dimaksudkan untuk menghilangkan kecenderungan responden memilih jawaban netral (jawaban tengah) (Widyoko, 2012). Jawaban netral (jawaban tengah) dapat memberikan arti ganda yaitu dapat berarti ragu-ragu atau responden belum dapat memutuskan atau memberikan jawaban. Selain itu, adanya pilihan jawaban netral juga mendorong responden untuk memilih alternatif jawaban tengah, terutama responden yang ragu-ragu dan belum dapat memutuskan jawaban ke arah setuju atau tidak setuju. Isi angket sesuai dengan indikator, yaitu; (1) Perencanaan pembelajaran terdiri dari program tahunan dan program semester, silabus, rencana pelaksanaan pembelajaran, kriteria ketuntasan minimal, agenda harian guru; (2) Pelaksanaan proses pembelajaran meliputi kegiatan pendahuluan, kegiatan inti, kegiatan penutup; (3) Penilaian Pembelajaran terdiri dari teknik penilaian, program remedial, analisis ulangan harian, program bimbingan peserta didik.

Instrumen penelitian yang digunakan pada penelitian ini adalah angket atau kuisioner. Sebelum menggunakan kuesioner, instrumen penelitian harus melalui uji validitas dan uji reabilitas terlebih dahulu untuk mengetahui keabsahan dari instrumen penelitian. Tujuan dari uji coba ini dilakukan agar instrumen tersebut benar-benar layak digunakan menjadi instrumen penelitian dan digunakan sebagai alat pengumpul data sehingga diperoleh data yang lengkap dan sistematis. Valid (layak) berarti instrumen tersebut dapat mengukur apa yang seharusnya diukur (Sugiyono, 2014).

\section{Uji Validitas Instrumen}

Validitas adalah tingkat kehandalan dan keahlian alat ukur yang digunakan (Sugiyono, 2003). Uji validitas menunjukkan sejauh mana alat pengukur itu mampu mengukur apa yang seharusnya diukur dalam kegiatan penelitian. Secara kuantitatif validasi instrumen ditunjukkan dengan besaran skor kuantatif hasil analisis data hasil uji coba empiris dengan teknik dan rumus statistik tertentu (Mukhadis, 2016).

Uji validitas melalui 2 tahap pengujian yaitu pengujian validitas konstruk dan pengujian validitas isi. Pengujian validitas konstruk dapat dilakukan dengan meminta bantuan para ahli (judment expert). Dalam penelitian ini yang menjadi ahli dalam validitas konstruk adalah Ahmad Mursyidun Nidhom. M.Pd. dan Dila Umnia Soraya, M.Pd. Hasil validitas instrumen dapat dilihat pada Tabel 2. 


\section{TEKNO Jumal Teknologi, Eektro, dan Keivuruan}

http://journal2.um.ac.id/index.php/tekno | ISSN 1693-8739

Hasil validitas isi angket dihitung dengan menggunakan Pers. (1):

$$
\% \text { Vs } x=\frac{\text { Jumla } h \text { skor penilaian }}{\text { Jumla } h \text { skor maksimum }} \times 100 \% \quad \text { Pers.(1) }
$$

Tabel 2. Expert Judgement

\begin{tabular}{llll}
\hline $\begin{array}{l}\text { Expert } \\
\text { Judgement }\end{array}$ & $\begin{array}{l}\text { Jumlah } \\
\text { Skor }\end{array}$ & Hasil Validasi & Kriteria Validasi \\
\hline M. Nidhom & 128 & $\%$ Vsx $=\frac{128}{152} \times 100=84,2 \%$ & Valid \\
Dila Umnia S & 145 & $\%$ Vsx $=\frac{145}{152} \times 100=95,3 \%$ & Valid \\
\hline
\end{tabular}

Setelah melalui pengujian oleh para ahli, maka instrument di uji cobakan ke sampel penelitian. Untuk instrumen yang berbentuk angket, maka pengujian validitas isi dapat dilakukan dengan membandingkan antara isi atau butir instrumen dengan indikator dari variabel. Pada instrumen angket yang digunakan peneliti terdapat 38 butir pertanyaan yang disertakan kolom komentar. Butir-butir instrumen selanjutnya di uji validitas isi dengan menguji coba pada guru produktif program keahlian Teknik Komputer dan Informatika dengan jumlah 8 responden.

Valid berarti instrumen tersebut dapat digunakan untuk mengukur apa yang seharusnya diukur (Sugiyono, 2003). Pengujian validitas instrumen dilakukan dengan bantuan SPSS. Hasil dari perhitungan validitas instrumen yaitu $r$ yang didapat $(r$ hitung $)$ kemudian dibandingkan dengan $r_{\text {tabel }}$ product moment untuk mengetahui validnya instrumen. Semakin tinggi nilai $x_{r y}$ maka semakin tinggi validitasnya, dengan demikian dapat diketahui butir pertanyaan atau pernyataan yang tidak memenuhi syarat (Riduwan dan Kuncoro, 2013). Hasil uji validasi pada penelitian terdapat 38 butir pertanyaan yang semua hasilnya valid. Hasil uji validitas dapat dilihat pada tabel 3.

Tabel 3. Data Hasil Validasi

\begin{tabular}{lll}
\hline Indikator & Valid & Tidak Valid \\
\hline Perencanaan Pembelajaran & $1,2,3,4,5,6,7,8,9,10,11,12,13$, & - \\
& $14,15$. & \\
Pelaksanaan & Proses & $16,17,18,19,20,21,22,23$. \\
Pembelajaran. & & - \\
Penilaian Pembelajaran & $24,25,26,27,28,29,30,31,32,33$, & - \\
& $34,35,36,37,38$. & \\
\hline
\end{tabular}

\section{Uji Reabilitas Instrumen}

Reliabilitas merupakan suatu instrumen cukup dapat dipercaya untuk digunakan sebagai alat pengumpul data karena instrumen tersebut sudah baik (Arikunto, 2010). Uji reliabilitas dilakukan untuk mengetahui seberapa jauh instrumen dapat dipercaya dan diandalkan sebagai alat pengumpul data sehingga mengungkap data yang bisa dipercaya. Dari teori tersebut dapat 


\section{TEKNO Jurnal Teknologi, Elektro, dan Kejuruan}

http://journal2.um.ac.id/index.php/tekno | ISSN 1693-8739

disimpulkan jika uji reliabilitas merupakan proses menguji butir-butir pertanyaan yang ada pada angket/tes apakah isi dari butir soal tersebut reliabel sehingga dapat mengukur faktornya.

Pengujian reabilitas menggunakan metode alpha Cronbarch dengan bantuan SPSS. Hasil pengujian reliabilitas untuk instrumen dengan responden guru menghasilkan nilai alpha 0,988 yang berarti seluruh butir soal pada instrumen pelaksanaan supervisi pembelajaran telah reliabel untuk digunakan pada penelitian dengan perincian sebagaimana Tabel 4.

Tabel 4. Hasil Reabilitas

\begin{tabular}{cc}
\hline Cronbach's Alpha & N of Items \\
\hline .988 & 38 \\
\hline
\end{tabular}

\section{Pengumpulan Data}

Pengumpulan data adalah cara yang dapat digunakan peneliti untuk mengumpulkan data penelitian (Arikunto,2010). Langkah-langkah pengumpulan data yang akan digunakan dalam penelitian ini, sebagai berikut:

\section{Teknik Angket/kuisioner}

Alasan digunakan angket (kuesioner) tertutup dalam penelitian ini adalah: (1) terjaminnya kerahasiaan responden, (2) memberikan peluang dan waktu yang cukup bagi responden untuk berfikir dan menjawab dengan leluasa, (3) dapat menjangkau banyak orang dalam waktu yang bersamaan, (4) terdokumentasi dan dapat direfleksi secara baik, dan (5) mudah dianalisis dan dapat dilakukan dengan tatap muka ataupun tidak (Syarifah, 2014).

Kuesioner dalam penelitian ini akan diberikan kepada seluruh guru produktif program keahlian Teknik Komputer dan Informatika di SMK Kota Batu untuk mengetahui seberapa tinggi pelaksanaan supervisi pembelajaran yang dilakukan oleh supervisor untuk membantu penyusunan rancangan pembelajaran, pelaksanaan pembelajaran dan mengevaluasi pembelajaran.

Kuesioner dalam penelitian ini berupa butir-butir pernyataan yang diberikan kepada guru untuk diisi, dengan cara memberikan tanda centang $(X)$ pada pilihan yang sudah disediakan. Bentuk kuesioner ini adalah kuesioner tertutup dan berskala. Tertutup karena pilihan jawaban sudah disediakan oleh peneliti, sehingga responden cukup menjawab sesuai dengan pilihan yang sudah ada. Skala yang digunakan dalam penelitian ini adalah skala likert dengan empat alternatif jawaban, sehingga responden dapat memberikan tanda centang $(X)$ pada jawaban yang tersedia.

\section{Analisis Data}




\section{TEKNO Jurnal Teknologi, Elektro, dan Kejuruan}

http://journal2.um.ac.id/index.php/tekno | ISSN 1693-8739

Mengolah data atau menganalis data adalah suatu proses mengubah wujud data yang telah diperoleh, biasanya masih termuat didalam instrumen atau catatan yang dibuat peneliti atau evaluator menjadi sebuah sajian data yang dapat disimpulkan dan diartikan (Arikunto, 2010). Teknik analisis data yang digunakan dalam penelitian ini adalah analisis deskriptif. Dalam pengelolaan data penelitian dapat dilakukan dengan beberapa cara sebagai berikut:

\section{Reduksi Data}

Setelah angket diisi oleh responden dan dikembalikan kepada penulis, penulis akan meneliti kelengkapan dalam pengisian angket apabila ada jawaban yang tidak dijawab, selanjutnya penulis menghubungi responden yang bersangkutan untuk menyempurnakan jawabannya.

\section{Penyajian Data}

Penyajian data dalam penelitian ini bertujuan untuk menjawab rumusan masalah dari penelitian ini yaitu untuk mengetahui seberapa tinggi pelaksanaan supervisi pembelajaran pada program keahlian Teknik Komputer dan Informatika Sekolah Menengah Kejuruan (SMK) di Kota Batu. Penyajian data dilakukan dengan memindahkan jawaban yang terdapat dalam angket ke dalam tabulasi atau tabel. Kemudian dilakukan penjumlahan total pada masing-masing sub variabel. Selanjutnya masing-masing jumlah total setiap sub variabel di analisis menggunakan SPSS dan dibuktikan menggunakan excel untuk mencari nilai mean, median, modus, standart deviasi, nilai maksimum, dan nilai minimum dari jumlah total masing-masing sub variabel. Data yang diperoleh dari perhitungan SPSS kemudian di hitung nilai rereta (Mi) dan simbangan baku ideal (SBi) untuk menentukan kategori pada masing-masing sub variabel pelaksanaan supervisi pembelajaran. Sehingga dalam penelitian ini digunakan rumus sebagai berikut:

Mengidentifikasi ketegori setiap sub variabel digunakan rerata ideal (Mi) dan simpangan

baku ideal (SBi) dengan menggunakan rumus sebagai berikut (Saifudin Azwar, 2002) :

$\mathrm{Mi}=$ Rata-rata Ideal

$\mathrm{Mi}=1 / 2$ (Skor tertinggi + Skor terendah)

$\mathrm{SBi}=$ Simpangan Baku

$\mathrm{SBi}=1 / 6$ (Skor tertinggi - Skor terendah)

a. Setiap sub variabel dikategorikan menjadi empat kategori seperti pada Tabel 5 (Saifuddin Azwar,2012):

Tabel 5. Kategori Skor Ideal Per Item Berdasarkan Distribusi Normal

\begin{tabular}{lll}
\hline No. & Norma Penilaian & Kategori \\
\hline 1. & $\mathrm{Mi}+1,5(\mathrm{SBi})$ s.d $\mathrm{Mi}+3(\mathrm{SBi})$ & Sangat Baik \\
2. & $\mathrm{Mi}$ s.d $\mathrm{Mi}+1,5(\mathrm{SBi})$ & Baik \\
3. & $\mathrm{Mi}-1,5(\mathrm{SBi})$ s.d Mi & Cukup Baik \\
4. & $\mathrm{Mi}-3(\mathrm{SBi})$ s.d Mi $-1,5(\mathrm{SBi})$ & Kurang Baik \\
\hline
\end{tabular}

b. Menghitung frekuensi responden pada setiap kualifikasi di setiap sub variabel dan variabel untuk selanjutnya dijadikan dalam bentuk persentase. Perhitungannya adalah dengan cara 


\section{TEKNO Jumal Teknologi, Eektro, dan Keivuruan}

http://journal2.um.ac.id/index.php/tekno | ISSN 1693-8739

membagi frekuensi tiap kualifikasi dengan jumlah responden dan dikalikan $100 \%$ atau pada Pers. (2).

$$
\mathrm{P}(\%)=\frac{\text { frekuensi yang muncul }}{\text { jumla h responden }} \times 100 \%
$$

C. Menyajikan hasil persentase frekuensi ke dalam bentuk diagram lingkaran yang terdiri dari empat kategori kualifikasi.

3. Penarikan Kesimpulan

Langkah terakhir adalah menarik kesimpulan dari hasil penelitian dan pembahasan. Data yang diperoleh dari angket selanjutnya disimpulkan secara deskriptif sesuai dengan fakta yang terjadi di lapangan.

\section{Hasil}

Penelitian ini membahas tentang pelaksanaan supervisi pembelajaran pada program keahlian Teknik Komputer dan Informatika Sekolah Menengah Kejuruan (SMK) di Kota Batu. Berdasarkan hasil pengumpulan data dengan cara membagikan angket kepada seluruh guru produktif (RPL, MM, TKJ) yang menjadi populasi penelitian.

Pelaksanaan supervisi pembelajaran dapat dideskripsikan dengan tiga sub variabel yaitu: menyusun rencana kegiatan tahunan dan semester, melaksanakan kegiatan pembelajaran (pendahuluan, inti, dan penutup), dan melaksanakan penilaian hasil belajar. Di bawah ini akan diuraikan hal-hal yang berkaitan dengan deskripsi data penelitian.

A. Penyusunan Rencana Kegiatan Tahunan dan Semester Oleh Guru Produktif Program Keahlian Teknik Komputer dan Informatika Sekolah Menengah Kejuruan (SMK) di Kota Batu.

Penyusunan rencana kegiatan tahunan dan semester terdiri dari 15 butir pernyataan yaitu nomor 1, 2, 3, 4, 5, 6, 7, 8, 9, 10, 11, 12, 13, 14 dan 15. Hasil analisis data secara statistik mengenai penyusunan rencana kegiatan tahunan dan semester yang dapat dilihat di dalam Tabel 6.

Tabel 6. Data Statistik Penyusunan Rencana Kegiatan Tahunan

\begin{tabular}{|c|c|c|}
\hline \multirow[t]{2}{*}{$\mathrm{N}$} & Valid & 26 \\
\hline & Missing & 0 \\
\hline Mean & & 40,65 \\
\hline Median & & 42,00 \\
\hline Mode & & 42 \\
\hline Std. Deviation & & 10,480 \\
\hline Minimum & & 22 \\
\hline
\end{tabular}

TEKNO Vol. 27 Issue 1, p15-29 | Jurusan Teknik Elektro, Universitas Negeri Malang, Indonesia | Maret 2017 G. Rahmadhita., T.A. Sutikno., I.M.Irawan.| Studi tentang pelaksanaan supervisi pembelajaran pada... 


\section{TEKNO Jumal Teknologi, Eektro, dan Kejuruan}

http://journal2.um.ac.id/index.php/tekno | ISSN 1693-8739

$\begin{array}{ll}\text { Maximum } & 59 \\ \text { Sum } & 1057\end{array}$

Berdasarkan Tabel diatas data statistik penyusunan rencana kegiatan tahunan dan semester guru produktif program keahlian Teknik Komputer dan Informatika Sekolah Menengah Kejuruan (SMK) di Kota Batu diperoleh nilai mean sebesar 40,65, nilai tertinggi sebesar 59, dan nilai terendah 22. Kategori penyusunan rencana kegiatan tahunan dan semester ditentukan dengan menghitung rerata ideal (Mi) dan simpangan baku ideal (SBi) sebagai norma pembanding setiap kategori. Adapun diperoleh hasil perhitungan sebagai berikut:

$\mathrm{Mi}=1 / 2 \times($ Skor tertinggi + Skor terendah $)$

$\mathrm{Mi}=1 / 2 \times(59+22)$

$\mathrm{Mi}=1 / 2 \times 81$

$\mathrm{Mi}=40,5$

$\mathrm{SBi}=1 / 6 \times$ (Skor tertinggi - Skor terendah)

$\mathrm{SBi}=1 / 6 \times(59-22)$

$\mathrm{SBi}=1 / 6 \times 81$

$\mathrm{SBi}=6,16$

Selanjutnya batasan kategori ubahannya dapat dilihat di dalam Tabel 7 (Azwar, 2012).

Tabel 7. Batasan Kategori Skor Ideal

\begin{tabular}{lll}
\hline No. & Norma Penilaian & Kategori \\
\hline 1. & $\mathrm{Mi}+1,5(\mathrm{SBi})$ s.d $\mathrm{Mi}+3(\mathrm{SBi})$ & Sangat Baik \\
2. & $\mathrm{Mi}$ s.d $\mathrm{Mi}+1,5(\mathrm{SBi})$ & Baik \\
3. & $\mathrm{Mi}-1,5(\mathrm{SBi})$ s.d Mi & Cukup Baik \\
4. & $\mathrm{Mi}-3(\mathrm{SBi})$ s.d Mi $-1,5(\mathrm{SBi})$ & Kurang Baik \\
\hline
\end{tabular}

Data diatas dapat diolah menjadi data pada table distribusi frekuensi pelaksanaan penyusunan rencana kegiatan tahunan dan semester. Dari hasil perhitungan angket pelaksaanaan rencana kegiatan tahunan dan semester oleh guru produktif program keahlian Teknik Komputer dan Informatika SMK di Kota Batu tahun 2016/2017 diketahui bahwa supervisi telah berlangsung dengan persentase tertinggi yaitu pada kategori baik (31\%). Hasil ini dirincikan pada Tabel 8.

Tabel 8. Distribusi Frekuensi Pelaksanaan Penyusunan Rencana Kegiatan Tahunan dan Semester

\begin{tabular}{ccccc}
\hline No. & Interval & F & Persentase & Kategori \\
\hline 1. & 49,74 s.d 58,98 & 7 & $27 \%$ & Sangat Baik \\
2. & 40,5 s.d 49,74 & 8 & $31 \%$ & Baik \\
3. & 31,26 s.d 40,5 & 6 & $23 \%$ & Cukup Baik \\
4. & 22,02 s.d 31,26 & 5 & $19 \%$ & Kurang Baik \\
\hline & Jumlah & 26 & $100 \%$
\end{tabular}

TEKNO Vol. 27 Issue 1, p15-29 | Jurusan Teknik Elektro, Universitas Negeri Malang, Indonesia | Maret 2017 G. Rahmadhita., T.A. Sutikno., I.M.Irawan.| Studi tentang pelaksanaan supervisi pembelajaran pada... 


\section{TEKNO Jumal Teknologi, Eektro, dan Kejuruan}

http://journal2.um.ac.id/index.php/tekno | ISSN 1693-8739

Tabel 8 merincikan bahwa hasil distribusi frekuensi pelaksaaan penyusunan rencana kegiatan tahunan dan semesteran memiliki nilai kategori sangat baik mendapat persentase (27\%) pada interval perhitungan 49,74 - 58,98, kategori baik (31\%) pada interval 40,5 - 49,74, kategori cukup baik (23\%) pada interval 31,26 - 40,5 dan kategori kurang baik didapat persentase sebesar (19\%) pada interval 22,02 - 31,26. Berikut rincian data hasil penelitian pada tabel diatas. Rincian nilai persentase masing-masing kategori dapat dilihat pada Gambar 1.

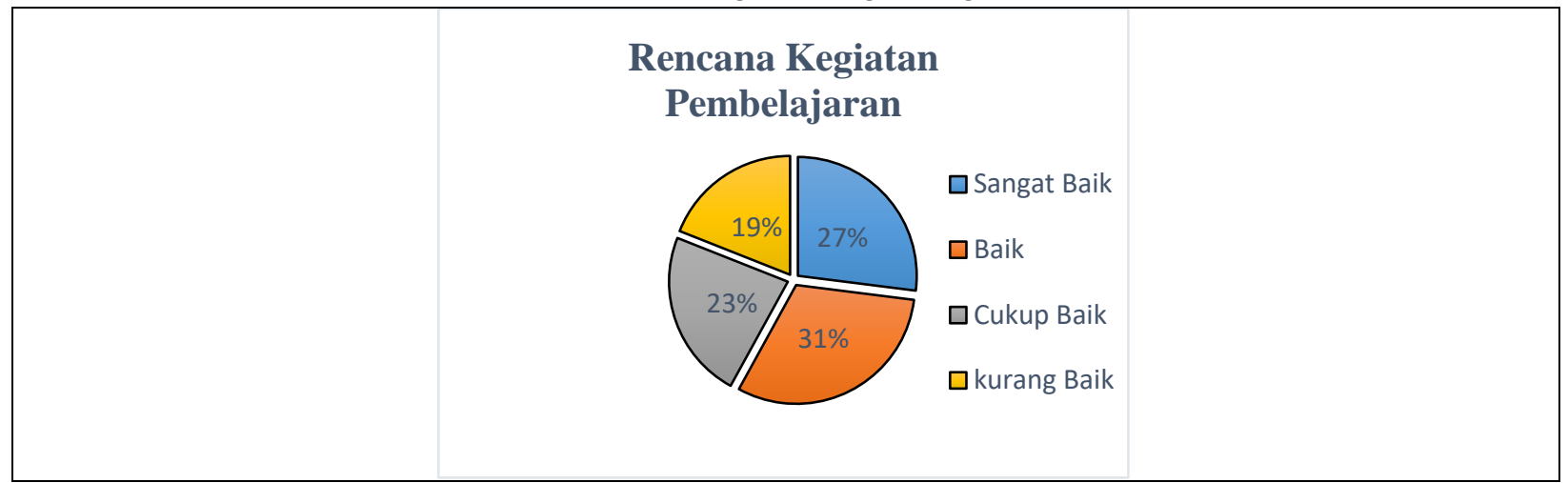

Gambar 1. Pie Chart Rencana Kegiatan Pembelajaran

\section{B. Pelaksanaan Kegiatan Pembelajaran Meliputi Pendahuluan, Inti, dan Penutup Oleh Guru Produktif Program Keahlian Teknik Komputer dan Informatika Sekolah Menengah Kejuruan (SMK) di Kota Batu.}

Pelaksanaan kegiatan pembelajaran meliputi pendahuluan, inti, dan penutup oleh guru produktif program keahlian teknik komputer dan informatika terdiri dari 8 butir pernyataan yaitu nomor 16, 17, 18, 19, 20, 21, 22 dan 23. Hasil analisis data mengenai pelaksanaan kegiatan pembelajaran yang dapat dilihat di dalam Tabel 9.

Tabel 9. Data Statistik Pelaksanaan Kegiatan Pembelajaran

\begin{tabular}{lll}
\hline $\mathrm{N}$ & Valid & 26 \\
\cline { 2 - 3 } Mean & Missing & 0 \\
Median & 22,54 \\
Mode & 24,50 \\
Std. Deviation & 27 \\
Minimum & 5,948 \\
Maximum & 10 \\
Sum & 30 \\
\hline
\end{tabular}

TEKNO Vol. 27 Issue 1, p15-29 | Jurusan Teknik Elektro, Universitas Negeri Malang, Indonesia | Maret 2017

G. Rahmadhita., T.A. Sutikno., I.M.Irawan.| Studi tentang pelaksanaan supervisi pembelajaran pada... 


\section{TEKNO Jurnal Teknologi, Elektro, dan Kejuruan}

http://journal2.um.ac.id/index.php/tekno | ISSN 1693-8739

Berdasarkan Tabel 1.9 data statistik pelaksanaan kegiatan pembelajaran meliputi pendahuluan, inti, dan penutup guru produktif program keahlian Teknik Komputer dan Informatika Sekolah Menengah Kejuruan (SMK) di Kota Batu diperoleh nilai mean sebesar 22,54 nilai tertinggi sebesar 30, dan nilai terendah 10. Kategori pelaksanaan kegiatan pembelajaran ditentukan dengan menghitung rerata ideal (Mi) dan simpangan baku ideal (SBi) sebagai norma pembanding setiap kategori. Adapun diperoleh hasil sebagai berikut:

$M i=1 / 2 \times($ Skor tertinggi + Skor terendah $)$

$\mathrm{Mi}=1 / 2 \times(30+10)$

$\mathrm{Mi}=1 / 2 \times 40$

$\mathrm{Mi}=20$

$\mathrm{SBi}=1 / 6 \times($ Skor tertinggi - Skor terendah $)$

$\mathrm{SBi}=1 / 6 \times(30-10)$

$\mathrm{SBi}=1 / 6 \times 20$

$\mathrm{SBi}=3,3$

Dari hasil perhitungan dari pengukuran hasil belajar yang dapat diketahi bahwa pelaksaanaan kegiatan pembelajaran oleh guru produktif program keahlian Teknik Komputer dan Informatika SMK di Kota Batu tahun 2016/2017 memiliki nilai tertinggi pada kategori baik dengan persentase 50\% pada interval 24,95 - 29,9. Hasil ini dirincikan pada Tabel 10.

Tabel 10. Distribusi Frekuensi Pelaksanaan Kegiatan Pembelajaran

\begin{tabular}{ccccc}
\hline No. & Interval & F & Persentase & Kategori \\
\hline 1. & 24,95 s.d 29,9 & 13 & $50 \%$ & Sangat Baik \\
2. & 20 s.d 24,95 & 7 & $27 \%$ & Baik \\
3. & 15,05 s.d 20 & 2 & $8 \%$ & Cukup Baik \\
4. & 10,10 s.d 15,05 & 4 & $15 \%$ & Kurang Baik \\
\hline & Jumlah & 26 & $100 \%$ & \\
\hline
\end{tabular}

Berdasarkan Tabel 1.10 dapat dirincikan bahwa hasil supervisi memiliki nilai dengan kategori sangat baik mendapat persentase (50\%) pada interval perhitungan 24,95 - 29,9, Kategori baik (27\%) pada interval 20 - 24,95, kategori cukup baik (8\%) pada interval 15,05 - 20 dan pada kategori kurang baik didapat persentase sebesar (15\%) pada interval 10,10 - 15,05. Rincian persentasenya dapat dilihat pada Gambar 2. 


\section{TEKNO Jumal Teknologi, Eektro, dan Kejivruan}

http://journal2.um.ac.id/index.php/tekno | ISSN 1693-8739

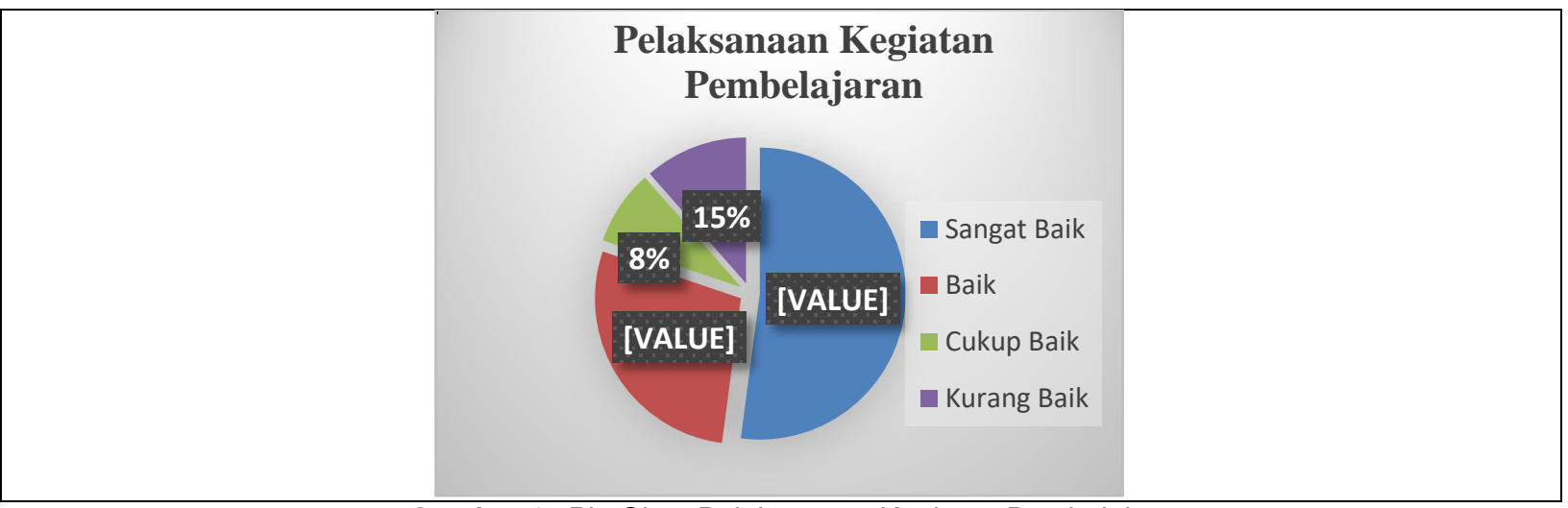

Gambar 2. Pie Chart Pelaksanaan Kegiatan Pembelajaran

\section{Pelaksanaan Penilaian Hasil Belajar Oleh Guru Produktif Program Keahlian Teknik Komputer dan Informatika Sekolah Menengah Kejuruan (SMK) di Kota Batu.}

Pelaksanaan penilaian hasil belajar oleh guru produktif program keahlian Teknik Komputer dan Informatika terdiri dari 15 butir pernyataan yaitu nomor 24, 25, 26, 27, 28, 29, 30, $31,32,33,34,35,36,37$ dan 38. Hasil analisis data secara statistik mengenai penyusunan penilaian hasil belajar yang dapat dilihat di dalam Tabel 11.

Tabel 11. Data Statistik Pelaksanaan Penilaian Belajar

\begin{tabular}{lll}
\hline $\mathrm{N}$ & Valid & 26 \\
\cline { 2 - 3 } Mean & Missing & 0 \\
Median & 41,92 \\
Mode & 43,50 \\
Std. Deviation & 35 \\
Minimum & 8,944 \\
Maximum & 21 \\
Sum & 58 \\
& & 1090 \\
\hline
\end{tabular}

Berdasarkan Tabel diatas data statistik pelaksanaan penilaian hasil belajar oleh guru produktif program Keahlian Teknik Komputer dan Informatika Sekolah Menengah Kejuruan (SMK) di Kota Batu diperoleh nilai mean sebesar 41,92 nilai tertinggi sebesar 58, dan nilai terendah 21. Kategori pelaksanaan penilaian hasil belajar ditentukan dengan menghitung rerata ideal (Mi) dan simpangan baku ideal (SBi) sebagai norma pembanding setiap kategori. Adapun diperoleh hasil perhitungan sebagai berikut:

$\mathrm{Mi}=1 / 2 \times($ Skor tertinggi + Skor terendah $)$

$\mathrm{Mi}=1 / 2 \times(58+21)$

$\mathrm{Mi}=1 / 2 \times 79$

TEKNO Vol. 27 Issue 1, p15-29 | Jurusan Teknik Elektro, Universitas Negeri Malang, Indonesia | Maret 2017

G. Rahmadhita., T.A. Sutikno., I.M.Irawan.| Studi tentang pelaksanaan supervisi pembelajaran pada... 


\section{TEKNO Jurnal Teknologi, Elektro, dan Kejuruan}

http://journal2.um.ac.id/index.php/tekno | ISSN 1693-8739

$\mathrm{Mi}=39,5$

$\mathrm{SBi}=1 / 6 \times($ Skor tertinggi - Skor terendah)

$\mathrm{SBi}=1 / 6 \times(58-21)$

$\mathrm{SBi}=1 / 6 \times 37$

$\mathrm{SBi}=6,16$

Selanjutnya dari hasil perhitungan penilaian hasil belajar oleh guru produktif program keahlian Teknik Komputer dan Informatika SMK di Kota Batu tahun 2016/2017 memiliki nilai tertinggi yaitu pada kategori Baik dengan persentase $46 \%$ pada interval 39,50 - 48,74, rinciannya ditampilkan pada Tabel 12.

Tabel 12. Distribusi Frekuensi Pelaksanaan Penilaian Hasil Belajar

\begin{tabular}{ccccc}
\hline No. & Interval & F & Persentase & Kategori \\
\hline 1. & 48,74 s.d 57,98 & 7 & $27 \%$ & Sangat Baik \\
2. & 39,50 s.d 48,74 & 12 & $46 \%$ & Baik \\
3. & 30,26 s.d 39,50 & 4 & $15 \%$ & Cukup Baik \\
4. & 21,02 s.d 30,26 & 3 & $12 \%$ & Kurang Baik \\
\hline & Jumlah & 26 & $100 \%$ & \\
\hline
\end{tabular}

Dari Tabel 1.12 diketahui bahwa hasil supervisi pada pelaksanaan pembelajaran memiliki nilai pada kategori sangat baik mendapat persentase $27 \%$ pada interval perhitungan 48,74 - 57,98, kategori baik mendapatkan persentase $46 \%$ pada interval 39,50 - 48,74, kategori cukup baik mendapat persentase $15 \%$ pada interval 30,26 - 39,50, dan pada kategori kurang baik didapat persentase sebesar $12 \%$ pada interval $21,02-30,26$. Rician data di atas dapat dikategorikan di dalam Gambar 3.

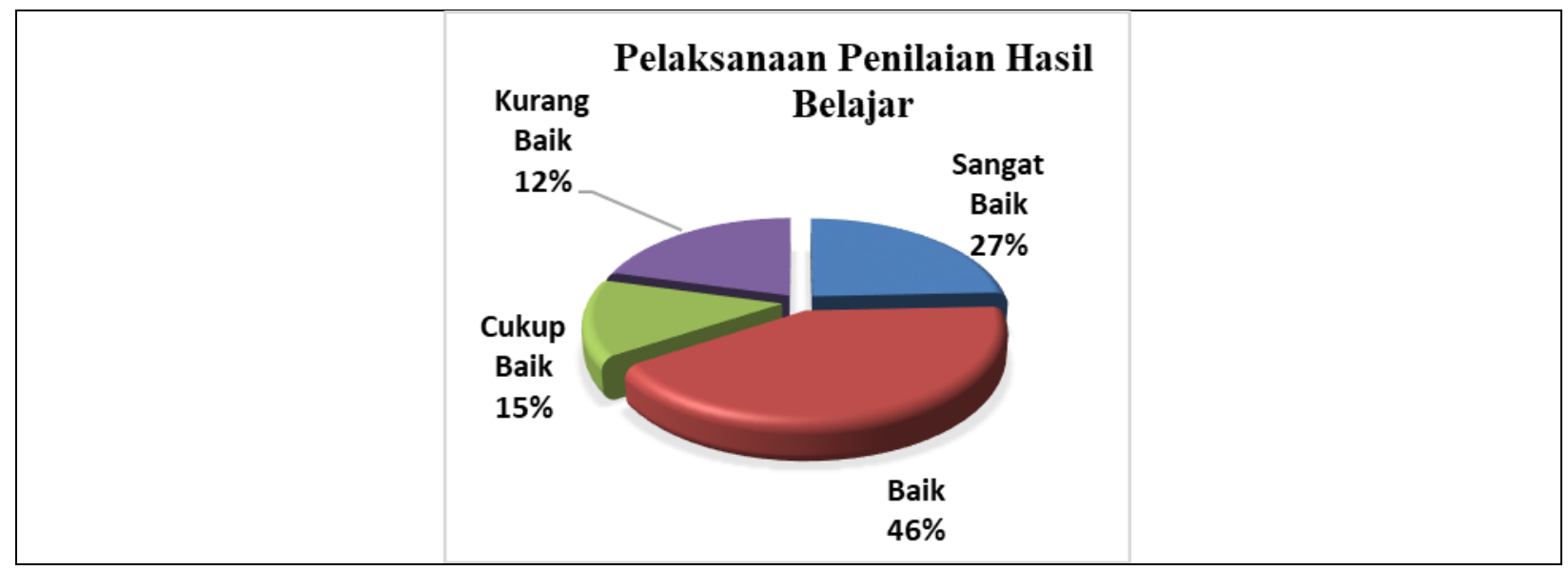

Gambar 3. Pie Chart Pelaksanaan Penilaian Hasil Belajar

\section{Kesimpulan}

Berdasarkan hasil penelitian, diperoleh kesimpulan sebagai berikut:

- Supervisi pada aspek penyusunan Rencana Kegiatan Tahunan dan Semester oleh guru produktif program keahlian Teknik Komputer dan Informatika Sekolah Menengah 


\section{TEKNO Jurnal Teknologi, Elektro, dan Kejuruan}

http://journal2.um.ac.id/index.php/tekno | ISSN 1693-8739

Kejuruan (SMK) di Kota Batu masuk dalam kategori baik. Guru telah mendapatkan bimbingan tentang materi perencanaan, pengaturan program tahuhan dan semester, cara pengembangan silabus, pemetaan standard kompetensi dasar, penentuan nilai KKM, penentuan strategi/metode dalam pembelajaran dan pembuatan instrumen penilaian dalam proses pembelajaran.

- Aspek proses supervisi pada pelaksanaan Kegiatan Pembelajaran meliputi pendahuluan, inti, dan penutup oleh guru produktif program keahlian Teknik Komputer dan Informatika Sekolah Menengah Kejuruan (SMK) di Kota Batu masuk dalam kategori "baik". Hal ini dibuktikan dengan guru telah mendapatkan bimbingan dalam menciptakan pembelajaran yang menggunakan strategi dan pendekatan yang memotivasi siswa, pembelajaran yang mensesuaikan isi kurikulum dengan kehidupan sehari-hari, pembelajaran yang menarik dan menimbulkan antusiasme belajar, dan pembelajaran yang menyenangkan dan dapat menarik perhatian siswa untuk fokus pada materi serta bimbingan dalam melakukan pembelajaran yang sesuai dengan rancangan yang telah disusun secara lengkap.

- Aspek penilaian supervisi pembelajaran ketiga yaitu Pelaksanaan Penilaian Hasil Belajar oleh guru produktif program keahlian Teknik Komputer dan Informatika Sekolah Menengah Kejuruan (SMK) di Kota Batu. Dari hasil penelitian ketahui bahwa supervisi ini telah berlangsung dengan "baik", hal ini dibuktikan dari hasil angket menunjukkan aspek ini tergolong dalam kategori baik. hal ini dibuktikan sebagai berikut: (a) Pengawas memberikan bimbingan guru tentang cara mengenali karakteristik siswa berdasarkan hasil belajar siswa; (b) Pengawas memberikan pengarahan kepada guru tentang memperhatikan feedback peseta didik, dan cara mengidentifikasi bakat, potensi dan kesulitan belajar hasil belajar siswa; (c) Pengawas membantu guru dalam mengevaluasi hasil belajar siswa untuk perbaikan pembelajaran selanjutnya.

\section{Daftar Rujukan}

Aqib, Z. \& Rohmanto, E. 2007. Membangun Profesionalisme Guru \& Pengawas Sekolah. Bandung: Yrama Widya.

Arikunto, Suharsimi. 2010. Prosedur Penelitian Suatu Pendekatan Praktik. Bandung: PT Rineka Cipta.

Barnawi \& Arifin, A. 2014. Meningkatkan Kinerja Pengawas Sekolah. Yogyakarta: AR-Ruzz Media.

Daryanto \& Rachmawati, T. 2015.Supervisi Pembelajaran: Inspeksi meliputi Controlling, Correcting, Judging, Directing, dan Demostration. Yogyakarta: Gava Media.

Imron. Ali. 2011. Supervisi Pembelajaran Tingkat Satuan Pendidikan. Jakarta: Bumi Aksara. Mukhadis. 2016. Sosok Manusia Indonesia Unggul Dan Berkarakter Dalam Bidang Teknologi Sebagai Tuntutan Hidup Di Era Globalisasi. Jurnal Pendidikan Karakter 2(2): 115-136.

TEKNO Vol. 27 Issue 1, p15-29 | Jurusan Teknik Elektro, Universitas Negeri Malang, Indonesia | Maret 2017

G. Rahmadhita., T.A. Sutikno., I.M.Irawan.| Studi tentang pelaksanaan supervisi pembelajaran pada... 


\section{TEKNO Jurnal Teknologi, Elektro, dan Kejuruan}

http://journal2.um.ac.id/index.php/tekno | ISSN 1693-8739

Sugiyono. 2003. Profesionalisasi Manajemen Pendidikan Kejuruan di Indonesia. Pidato Pengukuhan Guru Besar di Universitas Negeri Yogyakarta, 30 Agustus 2003. Yogyakarta: Tidak Diterbitkan.

Widyoko, E.P. 2012. Teknik Penyusunan Instrumen Penelitian. Yogyakarta: Pustaka Pelajar.

Winarno, M. E. 2013. Metode Penelitian Dalam Pendidikan Jasmani, Malang: Universitas Negeri Malang (UM PRESS). 